\title{
Challenges of Housing Finance and It Implications on Home Ownership by the Low and Medium Income Earners in Nigeria (A Case Study of Port Harcourt, Rivers State)
}

\author{
Nubor, Paul Kelvin \\ Department of Estate Management and Valuation, KenuleSaroWiwa Polytechnic P.M.B., 20 Bori, Rivers State, \\ Nigeria.
}

\begin{abstract}
Finance for housing development has become a perennial problem to certain categories of individuals in Nigeria. As a result of this financial need, the government devised a means of raising fund through compulsory deductions of $2.5 \%$ from workers earnings following the enactment of the National Housing Policy (NHP).The Federal Mortgage bank of Nigeria became the regulatory body through which the fund can be accessed by the Primary Mortgage Institutions (PMIs) and in turn disburse to the contributors in the form of housing finance loan. This study examines the challenges of financing housing development for the low and medium income earners in Port Harcourt, Rivers State, Nigeria. The study explores the sources of housing finance available to the low and medium income earners as well as the requirements for accessing housing loans through the PMIs, performance of the PMIs and most importantly ways of mitigating the problems low and medium income earners face in accessing housing finance loans. To achieve these objectives, the structured and unstructured questionnaires were designed for the study. Three hundred and eighty five structured questionnaires were administered to the low and medium income earners and five unstructured questionnaires were administered to the officials of the PMIs. The quantitative method was used for data analysis and the result of the analysis shows that the difficult requirements laid down by the PMIs to grant housing loans have prevented the low and medium income earners from having access to the National Housing Fund through the PMIs. The study also revealed that if the informal sources are advanced upon, it can serve as an alternative source of housing finance. The study suggests that stringent measures should be put in place to check the activities of the PMIs.
\end{abstract}

Keywords: Finance, home ownership, low/medium income.

\section{Introduction}

The planning, financing, construction and management of low income housing is of great concern to stakeholders in the housing development sector. Housing is known to have a profound influence on the health, efficiency, social behaviour and general welfare of the people (Abimaje, Akinbohungbe, and Ndalai, 2014). This is also in tandem with the (United Nations high Commissioner for Human Rights, 1948) declaration that affirms housing as very crucial to the survival, welfare and health of every individual.

Despite the effort made over the years by coming up with several housing intervention programs with the sole objective of making housing available to the majority of the population, the adequate supply of this commodity is still lacking in major cities in Nigeria. After food, housing has been universally accepted as the second most important need and very indispensable to the physical survival of man. (Akeju, 2007) and ( Nubi,2002) mentioned that decent housing is one of the basic needs of every individual, family and one of the best indices for measuring the standard of living of people across the society. The house/accommodation an individual inhabits in some cases reflects the status and even social acceptance in the society (Sanusi, 2003).

In Port Harcourt, housing provision is fraught with a lot of problems especially for the low and medium income earners who are obviously seen to constitute about $75 \%$ of the population.

The present situation that is being faced in Nigeria is similar to what was experienced in the United States until the Roosevelt administration (1933 through 1945) formed the Federal Housing Administration (FHA) to ensure insurance is provided against mortgage defaults for lenders. This step that was taken gave the federal housing administration and lenders in the USA more potency in the mortgage market. Today the USA housing finance system is used as a model for most mortgage markets (Policy gnosis, 2011) The focus on mortgage finance is very prominent because housing provision requires huge capital which is often beyond the capacity of the low and medium income groups in Nigeria. Housing finance to this group of people has often been fingered as one of the most formidable constraints in the housing sector in Nigeria. (Sanusi 2003).

Various scholars have different opinions on the issues of housing finance in Nigeria. (Onibokun, 1985) Considered land acquisition and documentation which involve huge capital to form a major hindrance to house ownership for low/medium income earners. (Omirin, 1998) Critically posits that it is wrong to always consider 
land accessibility as the greatest challenge to potential house owners. She went further to state that lack of finance and ever increasing interest rate has taken precedence over land accessibility. (Nnametu, 2012) Emphasizes housing finance vis-a-vis income of individuals. (Olusola, Aina , \& Ata, 2002) Identified lack of low credit facility as one of the major challenges hindering adequate house delivery. It is obviously clear from the foregoing how finance appears to be a major factor in housing delivery. Adequate financing is key to every successful housing development. Nigeria in the last two decades has had an outstanding restructuring of its housing finance system including the National Housing Policy which was geared towards creating an enabling environment for the generation of housing finance. However, this has not given a lasting solution to the challenges low and medium group face in accessing loanable funds to finance their own house. The National Housing Policy established a two tier system where the Federal Mortgage Bank of Nigeria( FMBN) became the apex mortgage institution and a regulatory agency with the supervisory role over large number of Primary Mortgage Institutions(PMIs) scattered all over the country. There has been a remarkable growth in the number of Primary Mortgage Institutions, currently there are about 101 PMIs with total assets of 333 billion (about 2.2 billion US dollars) of which about $25 \%$ are said to be invested in housing by the PMIs. This has not also given a lasting solution to the challenges low/medium income earners face in accessing loanable fund for housing development. (Taiwo, Adeboye, \& Aderonmu, 2014) The accessibility of fund from the Primary Mortgage Institution is quite cumbersome as the low /medium income earners in most cases do not have land title / document that would be required of them by the PMIs to access the fund. Property developers i.e. the private sector that are expected to carryout mass housing development scheme for low/ medium income earners to rent at subsidized price do not also have sufficient equity capital and access to loan, tend to attract high interest rate which could cause discouragement. Unfortunately the low/ medium income earners who are the most affected in terms of housing deficit are the ones who are also finding it difficult to have access to fund through the formal sources of finance. Basically, this study will explore the formal sources of finance and also delve into the informal sources to possibly find ways of bridging the gap which has been created due to the weaknesses of the formal sector.

\subsection{Sources of finance for housing development in Nigeria}

\section{Review of Literature}

Raising finance for housing development has become more like an insurmountable barrier making credit financing very inevitable. (Ademuliyi, 2010)

Housing finance can be narrowed to equity and borrowed capital.

The formal sources are usually debt financing through loanable fund from financial institutions.

(Ajibola, Oloyede and Oni, 2009)opined that debt financing is very common but constrained by long term nature of the housing development as against the short term period of the lenders in most cases. The informal sources are mainly traditional; they are loans from traditional money lenders, social clubs, and cooperative contributions. As good as these sources are in the traditional setting, the complex economic situation and the need for huge capital requirement for housing development has made them grossly inadequate. On the contrary (Adedeji and Abiodun, 2012) asserted that the activities of cooperative societies which also form a part of the informal sources have been impressive inrecent years. They wentfurther to state that cooperative societies are organised as social associations with a deeper sense of commitment to financial activities of their members. In addition to releasing housing finance loan to members, cooperative societies also encourage members to save towards buying a house. Evidently, from the argument of (Adedeji and Abiodun, 2012), it is clear that the informal sector is thriving towards bridging the gap created by the formal sector to stimulate housing provision in Nigeria. Examples are the cooperative thrift and credit union (CTCU) and Owolowo union. These unions funded the construction of block of flats that were allotted to members at subsidized prices. Evidence from China has also shown that the informal source of finance is thriving in other developing countries as the Chinese private firms are taken advantage of the informal source to grow private firms. (The society for Financial studies, 2010).

\subsection{Challenges of housing development finance in Nigeria}

According to(Arilesere, 1997), (Abiodun, 1999) and (Okupe \& Windapo, 2000)the historical antecedent of housing finance in Nigeria has been very appalling. The leap from the era of agriculture to petroleum really did not help.(Adebamowo, Oduwaye and Oduwaye, 2009). Confirmed that the most challenging aspect of housing development in Nigeria is the poor availability/accessibility of low credit facilities. In this regard, the onus lies on the formal sector to make finance available for housing development as some mortgage institutions will prefer to grant loans to other business ventures that will accept to pay high interest rate instead of the low and medium income earners with low income and cannot afford to pay high interest rate. (Nubi,2003) highlighted the challenges of housing finance to include i) cost of development and income ii) High cost of land iii) Poor access to compulsory savings iv) High interest rate. (Zubairu, 2000) In agreement with (Nubi, 2003) also considered these factors as major challenges of housing finance facing the low and medium income earners. 


\subsection{Possible Ways of Mitigating HousingFinance problem in Nigeria}

- The housing fund contribution should be included in the personal income taxation system so that a defined proportion of taxes will be allocated to the housing fund as it is practice in Singapore

- Large scale securitization of mortgage portfolios should be encouraged as a mechanism to strengthen and drive the housing finance system in Nigeria. This practice is prominent in other developed countries e.g. USA, Germany, France, South Korea (Sanusi, 2003)

- The cooperative, savings and credit institutions are complementary organisations in the housing finance sector and so, they should be encouraged to help make housing development finance available for the low and medium income earners.

- The current state of housing deficit in the country is very alarming and requires millions of housing unit to fill the gap. There is dire need for a comprehensive approach through a ministry whose day to day responsibilities and activities will be to research on housing issues. The financing of housing programs should be considered as a national responsibility. The private sector should be encouraged to invest in providing fund for housing development. (Nubi, 2002)

- Government has to draw up objectives to ensure a radical development of the rural areas to prevent rural/urban drift. Policies of government that encourages rural development will reduce unemployment, slum formation and the ever increasing demand for housing in the cities and urban centres. (Nubi, 2002)

- There have been complaints by the Primary Mortgage Institutions that the conditions put forward by FMBN to access fund are too stringent. The report of disbursement of fund by the FMBN should be examined. It must be of great concern to the FMBN to ensure easy access to housing loans as their achievement can only be measured based on their contribution to the countries housing stock. FMBN should also be reengineered to ensure that serious research is conducted into providing cheaper building materials and the development of building industries. (Chionuma, 2000)

\subsection{Appraisal of the Nigerian housing sector}

The Nigerian housing sector upon which the growing population is estimated to be over 150million and covers land area of 923770sqm is becoming worrisome with the continuous rural/urban drift couple with increase in building materials, labour and housing accessories. Demand pressure for housing has caused the hike in rent and consequently creating housing crisis for many Nigerians. The resultant effect is the development of slums scattered all over the city and towns in Nigeria. In view of the worrisome situation, a development strategy tagged "vision 2020" was proposed by the government in 2010. Vision 2020 targets a construction of 10,398,650 housing units from 2012 to 2020 which is about 1,115,406 housing units per annum at an average cost of USD 50,000 per house the total amount annually required for the investment is US $\$ 57,770,300,000$ mean while the current funding from housing financers is not more than USD 2billion.( Finmark, 2010)

Table 1 below shows vision 2020 housing requirement from 2012-2020

\begin{tabular}{|l|l|l|}
\hline Year & Houses to be built nationwide & Average number of houses per state \\
\hline 2012 & 500,000 & 12,500 \\
\hline 2013 & 600,000 & 15,000 \\
\hline 2014 & 720,000 & 18,000 \\
\hline 2015 & 864,000 & 21,600 \\
\hline 2016 & $1,036,000$ & 25,920 \\
\hline 2017 & $1,244,000$ & 31,104 \\
\hline 2018 & $1,492,992$ & 37,325 \\
\hline 2019 & $1,781,590$ & 44,790 \\
\hline 2020 & $21,495,908$ & 53,748 \\
\hline Total & $10,398,650$ & 259,987 \\
\hline
\end{tabular}

Source: (Sam, 2010)This day Newspaper Aug 3, 2010

\subsection{Nigerian Housing Sector and other Countries}

In several countries in the world the housing sector has become one of the most productive and viable industry while in the developing countries, the rate of urbanization is so overwhelming such that the federal, state and local government lack the capacity to plan and meet the housing need of the people. The sub-prime mortgage crisis that occurred in USA and affected most of the world's capital market created an adverse effect on housing credit and value. The situation is improving due to the strength of the underline household asset and better regulation posed by the relevant sectors. For example in Mexico, the success stories was recorded due to the ability of the country to attract hug fund from America because of the strong regulations and foreclosure laws in the housing sector which could reduce the rate of risk. In the UK, it was about the remarkable success in the provision of public and social housing. In other European countries, it was hinged on developing a robust 
mortgage bond market to ease access to credit.In Nigeria obviously, housing condition is poor as a result of poor housing finance, poor access to land, weak legislations, poor infrastructures etc.(Policygnosis, 2011)

\subsection{Study Area}

Port Harcourt is considered appropriate for this study for a number reasons: first,

Port-Harcourt is a seat of commercial activities in Nigeria, it lies along the Bonny coastal line and located in the Niger delta area of Nigeria. Port-Harcourt is a large industrial centre with a good number of multi-national firms carrying out activities related to petroleum products. It is a major oil refining city in Nigeria with two oil refineries that processes an estimate of 200,000 barrels of crude oil per day. Port-Harcourt is the capital city of Rivers State which is one of the richest state in Nigeria in terms of foreign exchange and revenue from the oil industry.Population drift into Port Harcourt city in the past two decades has been quite alarming thereby making the demand for housing a burning issue for certain categories of people.

\subsection{Sampling design:}

\section{Methodology}

The study population comprises of the low and medium income earners within the study area. Primary data were gathered as a result of well-structured questionnaires administered to the Low and medium income earners. Three hundred and eighty five out of four hundred questionnaires administered were duly completed and therefore considered satisfactory for analysis, this represents $96 \%$ response rate which is good enough for reliability and valid conclusion. Data obtained were analysed using the descriptive and inferential statistics. The statistical tool used helped to show the variation in opinion of the low and medium income earners in the study area. The results were properly arranged and tabulated to allow for meaningful analysis and interpretation.

\section{Data Analysis And Discussion}

Analysis of responses are presented in tables and charts. The 4 and 5 points Likert scale analysis are used to weigh the various challenges faced by the low and medium income earners. The hypotheses of the study were tested using Analysis of Variance (ANOVA) to determine the correlational relationship between some dependent and explanatory variables on the perceptions of the low and medium income earners regarding access to PMI loans and the performance of the PMIs in granting housing finance loans. The varied views of respondents on how to mitigate the housing finance problem is also presented on tables and charts.

Table 2: Distribution of Respondents who are House Owners

\begin{tabular}{|l|l|l|}
\hline S/N & Responses on House Ownership & Frequency \\
\hline 1 & YES & 84 \\
\hline 2 & NO & 381 \\
\hline & Total & 385 \\
\hline
\end{tabular}

Researcher's field survey 2017

Table 2 above shows that 84 of the medium and low income earners own house(s) of their own. A total of 381 do not own a house yet.

\subsection{Access to Primary Mortgage Institutions (PMIs)}

Table 3: Responses on access to housing loanthrough the Primary Mortgage Institutions (PMIs)

\begin{tabular}{|l|l|l|}
\hline S/N & $\begin{array}{l}\text { Access to Primary Mortgage } \\
\text { Institutions }\end{array}$ & Frequency \\
\hline 1 & YES & 87 \\
\hline 2 & NO & 298 \\
\hline & Total & 385 \\
\hline
\end{tabular}

Researcher's Field survey 2017

Table 3 above shows that 87 of the medium and low income earners have access to housing loan through the Primary Mortgage Institutions (PMIs) as 298 of them have not been granted housing loan through the Primary Mortgage Institutions (PMIs).

Table 4: Responses on Challenges faced in Raising Housing Finance

\begin{tabular}{|l|l|l|l|l|l|}
\hline Challenges & Strongly Agree & Agree & Disagree & Strongly Disagree & Total \\
\hline High Interest Rate Charged by PMIs & 186 & 102 & 55 & 42 & 385 \\
\hline $\begin{array}{l}\text { Difficulty in accessing National } \\
\text { Housing Fund (NHF) }\end{array}$ & 193 & 129 & 22 & 41 & 385 \\
\hline Poor Income & 178 & 162 & 34 & 19 & 385 \\
\hline Lack of collateral & 249 & 82 & 45 & 9 & 385 \\
\hline
\end{tabular}

Source: Field Survey 2017 
Fig1: Bar Chart showing Challenges faced by Respondents in Raising Housing Finance

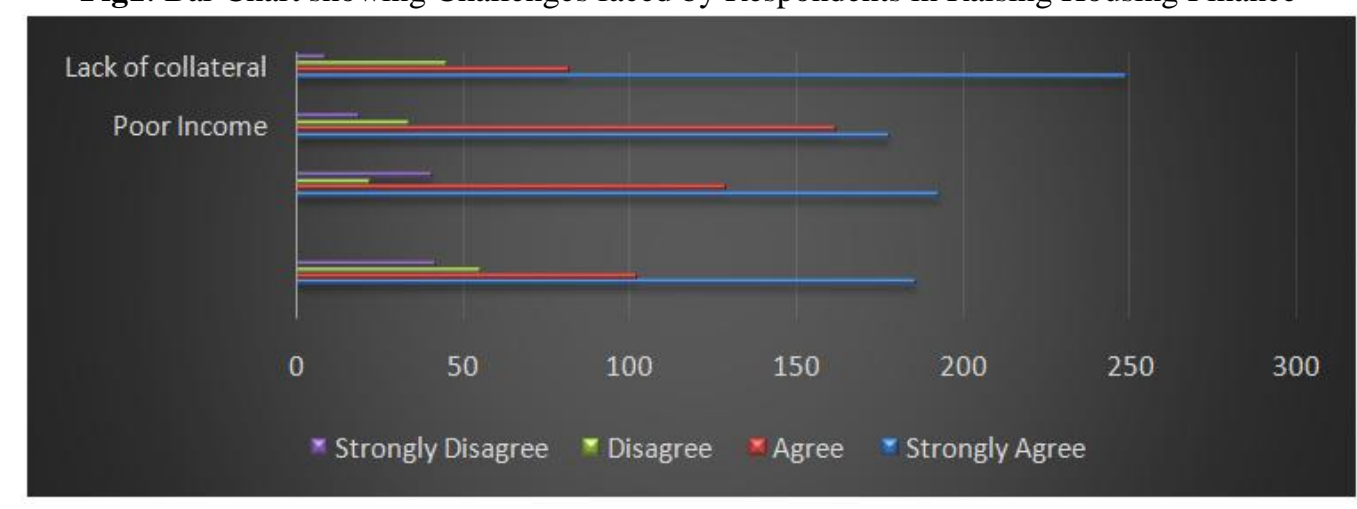

Table 4and the bar chart above provide responses to the challenges faced by the low and medium income earners in sourcing for housing development finance in Nigeria. It shows that 186, 102, 55, and 42 of the respondents strongly agreed, agreed, disagreed and strongly disagreed respectively that 'high interest rate charged by PMIs' are the challenges faced by medium and low income earners in raising housing finance. And also 193, 129, 22, and 41 of the respondents strongly agreed, agreed, disagreed and strongly disagreed respectively that 'difficulty in accessing National Housing Fund (NHF)' is a challenge faced by medium and low income earners in raising housing finance. Again 178, 162, 34, and 19 of the respondents strongly agreed, agreed, disagreed and strongly disagreed respectively that 'poor income' is a challenge faced by medium and low income earners in raising housing finance. Lastly, 249, 82, 45, and 9 of the respondents strongly agreed, agreed, disagreed and strongly disagreed respectively that 'lack of collateral' is a challenge faced by medium and low income earners in raising housing finance.

Table 5: Difficult Requirements for Accessing Housing Loans from PMIs

\begin{tabular}{|l|l|l|l|l|l|}
\hline Very Difficult & Little Difficult & Normal & Not Difficult & Mean & Decision \\
\hline 237 & 74 & 34 & 50 & 3.35 & Accepted \\
\hline
\end{tabular}

Researcher's field survey 2017

The result presented in Tables 5 shows that the low and medium income earners in Port Harcourt consider the requirement for accessing housing loans from PMIs to be difficult. This answer is based on the mean response score of 3.35 that is greater than the required 2.50 mean response score in the case of 4-point Likert scale.

Table 6: Performance of PMIs in Granting Housing Finance Loan

\begin{tabular}{|l|l|l|l|l|l|l|l|}
\hline PMIs Performance Indicators & Excellently & Good & Poor & Very Poor & Mean & Decision \\
\hline $\begin{array}{l}\text { Granting of loans or advances to } \\
\text { any person for the building } \\
\text { improvement or extension of a }\end{array}$ & & 78 & 97 & 165 & 2.01 & Rejected \\
dwelling/commercial house. & & & & & & \\
\hline $\begin{array}{l}\text { Granting loans and advances to any } \\
\text { person for the purchase or } \\
\text { construction } \\
\text { dwelling/commercial house. }\end{array}$ & & 43 & 127 & 185 & 1.79 & Rejected \\
\hline
\end{tabular}

Researcher's field survey 2017

Table 6above shows the mean response to the two items is less than 2.50. This implies that PMIs have performed poorly in the granting of loan to low and medium income earners for the improvement or extension and purchase or construction of dwelling/commercial house in Port Harcourt.

Table 7: Challenges faced by Low and Medium Income Earners in Accessing Housing Finance

\begin{tabular}{|l|l|l|l|l|l|l|}
\hline Challenges & Strongly Agree & Agree & Disagree & Strongly Disagree & Mean & Ranking \\
\hline $\begin{array}{l}\text { High Interest Rate } \\
\text { charged by PMIs }\end{array}$ & 186 & 102 & 55 & 42 & 3.12 & 4 th \\
\hline $\begin{array}{l}\text { Difficulty in accessing } \\
\text { National Housing } \\
\text { Fund (NHF) }\end{array}$ & 193 & 129 & 22 & 41 & 3.23 & $3 \mathrm{rd}$ \\
\hline Poor Income & 178 & & & & & \\
\hline Lack of collateral & 249 & 162 & 34 & 19 & 3.34 & $2 \mathrm{nd}$ \\
\hline
\end{tabular}

Source: Field Survey, 2017 
Table 7above shows mean responses of 3.12, 3.23,3.34 and 3.48 for high interest rate charged by the PMIs, difficulty in accessing National housing fund (NHF) poor income and lack of collateral respectively. This implies that lack of collateral is regarded as the major challenge faced by the low and medium income earners in accessing housing finance loan.

Table 8: Ways of Mitigating the Challenges of Housing Finance

\begin{tabular}{|l|l|l|}
\hline Ways of mitigating the housing finance problem & Frequency & Percentage \\
\hline Improve the Informal sector & 170 & $44 \%$ \\
\hline Review the Operational Structure of The PMIs & 80 & $20.7 \%$ \\
\hline Review CBN Policies on Interest rate & 70 & $18.1 \%$ \\
\hline Increase allocation of Government to boost The NHF & 40 & $10.3 \%$ \\
\hline Encourage the low and medium Income To Contribute towards the NHF & 25 & $6.5 \%$ \\
\hline
\end{tabular}

Researcher's Field Survey 2017

Table 8 above shows the responses on ways of mitigating the challenges of housing finance faced the low and medium income earners. 170 out of 385 respondents representing $44 \%$ are of the opinion that improving the informal sector will help mitigate housing finance problem faced by the low and medium income earners. 80 respondents representing $20.7 \%$ are of the view that if the structure of the Primary Mortgage Institution is reviewed, it will help to address the problem. $18.1 \%, 10.3 \%$ and $6.5 \%$ are of the view that reviewing the central bank policy on interest rate, increasing government allocation to boost the National Housing Fund and encouraging the low and medium income earners respectively to contribute towards the National Housing Fund are ways of mitigating the housing finance problem.

Fig. 2

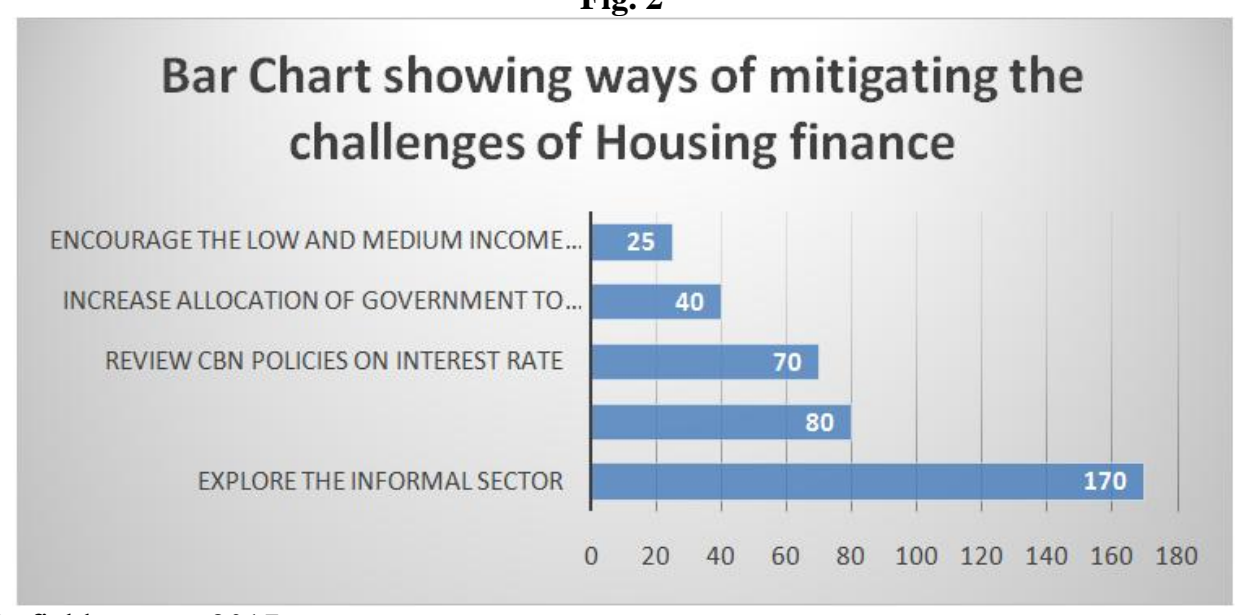

Researcher's field survey, 2017

\subsection{INFERENTIAL STATISTICS (ANOVA) FOR TEST OF HYPOTHESES}

As stated earlier responses are also analysed using the inferential statistics (ANOVA) to test the correlational relationship between the perceptions of the low and medium income earners on the following issues;

- Difficulties in the requirement for accessing housing finance loan through the primary mortgage institution.

- The performance of the primary mortgage institution in granting housing finance loan.

The test of hypotheses were carried out using (SPSS) to ensure that all results yielded are accurate. To carry out this analysis, two different categorical variables will be tested against each other to see if there is any significant difference between them. Results from each test will be presented in a cross-tabulation table generated through SPSS and this will be analysed and discussed in detail one after the other. This format is selected because it allows the information to be displayed comprehensively for easy understanding to the readers and also the researcher will be able to analyse results accurately and in a logical manner.

\subsection{Hypothesis One}

This test compares the views or perceptions of the low and medium income earners on the difficulties in the requirement for accessing housing loans through the PMIs. This analysis will help to confirm the result in table 5 using a descriptive analysis on a 4-point Likert scale to weigh the difficulties faced by the low and medium income earners in accessing housing finance. 
The Null Hypothesis H0 states thus: There is no significant difference between the perceptions of low and medium income earners on the difficulties in the requirement for accessing Housing Loans through the PMIs.

Table 9- ANOVA Result on difficulties in the requirement for accessing Housing finance Loans from the PMIs.

\begin{tabular}{|l|l|l|l|}
\hline Variables & Total No. & F-stat. & Sig. \\
\hline $\begin{array}{l}\text { Perception of Low Income Earners on } \\
\text { difficulty in requirement for accessing } \\
\text { Housing Loans from PMIs. }\end{array}$ & & 1.69 & 0.19 \\
\hline $\begin{array}{l}\text { Perception of Medium Income Earners on } \\
\text { difficulties in requirement for accessing } \\
\text { Housing Loans from PMIs. }\end{array}$ & 179 & & \\
\hline
\end{tabular}

Source: Researcher's computation from Data Collected during survey

The result in table 9 above shows that the f-statistics is not significant at 5\% significance error. This implies that the null hypothesis of no significant difference in the perception of low and medium income earners regarding the difficulties in requirement for accessing Housing Loans from PMIs cannot be rejected. Therefore, there is no significant difference between the perception of low and medium income earners regarding the difficulty in requirement for accessing Housing Loans from PMIs.

\begin{tabular}{|c|c|c|c|c|c|c|}
\hline $\begin{array}{l}\text { Anova: Bngle Fado: } \\
\text { SIDMARY }\end{array}$ & & & & & & \\
\hline Grouts & Cowz & Sar. & Llvagag & Thian: & & \\
\hline Ion_ircert_exres & 2.6 & $.88: 6$ & $: 6.59697355$ & 53.96059691 & & \\
\hline 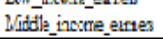 & 199 & 371 & 4.4375 & $41.7291666 i$ & & \\
\hline \multicolumn{7}{|l|}{ ANORA } \\
\hline Sources of Varution & 58 & 4 & MS & $\bar{F}$ & $P+x d y$ & $P_{\text {citt }}$ \\
\hline Beverer Fitop: & $9: 98.95$ & 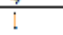 & 4.58194766 & 1689799768 & $0.194+351$ & $3.8585: 3636$ \\
\hline Mitzi G:ovos & $2: 4.29$ & 384 & 5.16792503 & & & \\
\hline Toz1 & $2: 5: 292$ & 385 & & & & \\
\hline
\end{tabular}

\subsection{Hypothesis Two}

This test compares the views or perceptions of the low and medium income earners on the performance of the Primary Mortgage Institution in granting housing finance loan. Thisis also in conformity with the analysis shown in table 6. The Null Hypothesis H0 states thus: There is no significant difference between the perceptions of low and medium income earners on the Performance of Primary Mortgage Institutions in Granting Housing Finance Loans The result in table 10 below shows that the f-statistics is significant at 5\% significance error. This implies that the null hypothesis of no significant difference between the perception of low and medium income earners on the performance of Primary Mortgage Institutions in Granting Housing Finance Loans can be rejected. Therefore, there is a significant difference between the perceptions of low and medium income earners on the performance of Primary Mortgage Institutions in Granting Housing Finance Loans.

Table 10: ANOVA Result comparing Perceptions of Performance of Primary Mortgage Institutions in Granting Housing Finance Loans

\begin{tabular}{|l|l|l|l|}
\hline Variables & Total No. & F-stat. & Sig. \\
\hline $\begin{array}{l}\text { Perception of Low Income Earners on Performance of } \\
\text { Primary Mortgage Institutions in Granting Housing }\end{array}$ & 206 & 6.65 & 0.01 \\
Finance Loans. & & & \\
\cline { 1 - 2 } $\begin{array}{l}\text { Perception of Medium Income Earners on Performance } \\
\text { of Primary Mortgage Institutions in Granting Housing } \\
\text { Finance Loans. }\end{array}$ & 179 & \\
\hline
\end{tabular}

Source: Researcher's computation from Data Collected during survey $\underset{\text { Frctor }}{\text { And }}$

\begin{tabular}{|c|c|c|c|c|c|c|}
\hline 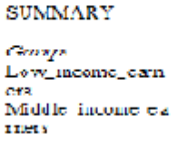 & $\begin{array}{l}\text { Cerame } \\
200 \\
178\end{array}$ & $\begin{array}{l}\text { Su } \\
m \\
1144 \\
14 \\
920 \\
3\end{array}$ & 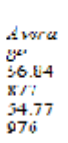 & 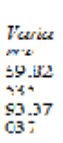 & & \\
\hline AlNove & & & & & & \\
\hline Sourse of Vaviaton & SSS & af & MSS & $\pi$ & valks & $\Gamma_{\mathrm{crit}}$ \\
\hline Between lirocp: & $\begin{array}{l}4 / 3.6 \\
34910\end{array}$ & 1 & $\begin{array}{l}+13.6 \\
71.23\end{array}$ & $\begin{array}{l}6.610 \\
26,\end{array}$ & $\begin{array}{l}0.010 \\
22 j^{\circ}\end{array}$ & $\begin{array}{l}3.850 \\
506\end{array}$ \\
\hline Withir. Gours & .44 & 384 & 804 & & & \\
\hline lota. & $\begin{array}{l}35300 \\
.44\end{array}$ & $30 \leqslant$ & & & & \\
\hline
\end{tabular}




\subsection{Conclusions}

\section{Conclusion And Recommendation}

This study takes an in-depth investigation into the accessibility level to housing finance by the low and medium income earners in Port Harcourt, this is due to their economically disadvantaged position which has made quality housing very unaffordable to them.

Based on the research findings, the following conclusions have been drawn from the study:

1) The processes for approving housing loans to the low and medium income earners are quite cumbersome and consequently contributed to the massive housing deficit in Port Harcourt, Rivers State, Nigeria.

2) The Primary Mortgage Institutions in some cases divert housing loans into other forms of business activities and as such the purpose for establishing the National Housing Fund (NHF) may have been defeated.

3) The study further revealed that the problem facing the low and medium income earners in accessing the National Housing Fund (NHF) which they are major contributors is basically lack of collateral which is as a result of high interest rate and poor income.

\subsection{Recommendations}

1)The Government can formulate policies to improve on the informal sources of finance and make it a reliable source of housing finance so as to bridge the gap created due to inefficiency and laxity characterising the formal sources.

2) There is need to review the existing structure of the Primary Mortgage Institutions; a well organised institutional framework with stronger legislations can be created to ensure the PMIs effectively carry out their functions.

3) Government authorities can formulate policies that will bring about a flexible requirements for obtaining housing loans through the Primary Mortgage Institutions and other financial institutions.

4) The budgetary allocation for housing should be reviewed so that more funds can be allocated to boost the National Housing Fund (NHF)

\section{References}

[1] Abimaje, J., Akinbohungbe, D. O., \& Ndlalai, B. A. (2014). Housing Affordability in Nigerian Towns: A case study of Idah, Nigeria. International Journal of Civil Engineering, Construction and Estate Management, I(2), 31-38.

[2] Abiodun, A. (1999). Housing finance under the National Housing Fund. NIgeria Institute of Town Planning.

[3] Adebamowo, M. E., Oduwaye, L., \& Oduwaye, O. S. (2009). Problems of mitigating housing finance through the primary mortgage institution in Lagos. International business and management journal, 4(1).

[4] Adedeji, Y. D., \& Abiodun, O. O. (2009). An evaluation of accessibilityof low incomeearners to housing finance in nigeria. The European scientific journal, 8(12).

[5] Ademuliyi, I. A. (2010). Public housing delivery strategy in Nigeria. Journal of sustenaible development in Africa, xii(12).

[6] Ajibola, O. M., Oloyede, S. A., \& Oni, A. O. (2009). Real Estate investment Trust: An attractive vehicle for real estate development in Nigeria. Journal of the Nigerian Institution Estate Surveyors and Valuers, 32(1).

[7] Akeju, A. A. (2007). Challenges to providing affordable housing in Nigeria. 2nd Emerging Urban Africa international conference on housing finance in Nigeria.

[8] Arilesere, D. (1997). Housing finance in Nigeria. NIOB workshop on affordable housing.

[9] Chionuma, O. M. (2000). The role of Primary Mortgage Institutions in the provision of housing in Nigeria. Workshop organised by Nigerian Institute of Quantity surveyors.

[10] ESRB. (2015). Report on commercial real estate and financial stability in the/

[11] Ezeudu, C. U. (2012). An evaluation of the impact of infrastructure on residential housing accomodation in Enugu urban and its environs.

[12] Finmark Trust. (2010). Overview of the housing finance sector in Nigeria.

[13] Jinadu, A. M. (2007). Understanding the basics of housing. Jos: Jos university press.

[14] Lawal, M. I. (2000). Estate deevelopment practice in Nigeria. Lagos: ILCO books and publishers.

[15] Nnametu, J. (2012). An evaluation of the adequate residential housing affordability by staffs of tertiary institutions in Owerri Unpublished master's thesis.

[16] Nubi, T. O. (2000). Housing finance in Nigeria-Need for re-engineering.

[17] Nubi, T. O. (2008). Affordable housing delivery in Nigeria. Souther African housing foundation international conferenceand exhibition

[18] Ogbonna , A. C. (2012). Vision 202020: The transformation agenda towards a modified intervention framework for housing. National conference of Nigerian Institution of Estate Surveyors and Valuers (NIESV).

[19] Okupe, L., \& Windapo, C. (2000). The role of the private sector in housing delivery in Nigeria. The Nigerian Institute of Building.

[20] Olusola, K. O., Aina, O., \& Ata, O. (2002). An appraisal of the suitability of laterite for urban housing in Nigeria. Proceedings of the faculty of EnvironmentaL design conference.

[21] Omirin, M. M. (1998). Land accessibility and low income building activity in metropolitan Lagos. Journal of environmental studies, 1(1), 76-79.

[22] Onibokun, P. (1985). Housing in Nigeria. Ibadan: University press.

[23] Policygnosis International . (2011). A feasibility study on the establishment of a secondary mortgage institution in Nigeria. Glenwoo

[24] Sam, O. (2010, August 3). This day newspaper.

[25] Sanusi, J. O. (2003). Mortgage financing in Nigeria: Issues and challenges. John wood Ekpenyong memorial lecture.

[26] Taiwo, A., Adeboye, A., \& Aderonmu, P. A. (2014). The role of the private sector in public private partnership in housing deliveryfor the low income in Nigeria.

[27] The society for Financial studies. (2010). THe review of financial studies. Oxford journals

[28] Un-Habitat. (2005). Financing urban shelter: Global report on human setlement.

[29] United Nations High Commissioner for human rights. (1948). UN-Habitat. Retrieved from www.ohchr.org

[30] Zubairu, M. (2000). Housing development in Nigeria. Workshop on financing and procurement of housing and infrastructure. 